familiar, features of the original work are retained: the information about economic and, particularly, medicinal plants, the extensive use of Unterreihen, and so on. There has, however, been a considerable rearrangement of the major taxa, the most conspicuous feature of which is the transfer of the Monocotyledoneae to the end. Perhaps of greater significance is the fact that the Pandanales, with which the original Engler sequence of orders started, are now placed near the end of the monocotylcdcns, presi mably an acceptance of the view that the apparent simplicity of their flowors is the result of reduction, not an indication of primitiveness.

In curious contrast to this is the retention of the apetalous dicotyledons in the traditional order at the beginning of that group, in spite of their syncarpous ovaries and the widely held view that anemophily is a secondary development in flowering plants. There is thus an apparently unexplained inconsistency between the principles adopted for classifying the monocotyledons and the dicotyledons. This is perhaps not very important. What does seem to be of much greater importance arises from the old, but often overlooked, question: "What is the purpose of this classification ?". The original Syllabus is the basis for tho arrangemont of many large herbaria and numerous Floras, and so forms a guide to thern; it is also so familiar to most taxonomists that when they want to look something up they rarely need to refer to the index. The new edition has, at present, neither of these merits and, because of the labour involved, no large herbarium will be rearranged according to it, so it will still be necessary for a working taxonomist to be familiar with the old Englor system and the Bentham and Hooker system, and perhaps some others.

The urge to 'improve' systems of classification by making them moro 'natural' is one to which many, perhaps most, taxonomists succumb sooner or later. It is an understandable and perhaps laudable urge, but it seems to me unfortunate when it is given rein in a standard work of reference. In such works, for practical purposes an unchanging classification, even though rather artificial, is the most convenient. It is interesting to see that the differences between the Engler and the Bentham and Hooker systems, formerly so great, are now diminished.

In spite of this drawback, the twelfth edition of the Syllabus is a most valuable reforence work, with its admirably clear descriptions of orders, sub-orders, families, sub-families and tribes, and the brief, but often illuminating, mention of important genora and species. It is particularly uscful to have notes on pollen morphology, embryological characters and anatomical peculiarities included in the family descriptions. The bibliography is extensive and up to date, though perhaps rather deficient in its coverage of Russian literature. There are, inevitably, a few misprints, for example, Astrodiscus for Astrodaucus and Bifora radicans for B. radians; otherwise the book is well printed and the illustrations are clear and informative. It is certainly a work to keep near at, hand.

T. G. T'UTIN

\section{PERISHABLE RICHES}

Fish as Food

Editod by Georg Borgstrom. Vol. 3: Processing, Part 1. Pp. xiv +489. 125s. Vol. 4: Processing, Part 2. Pp. xiv +518. 132s. (New York: Academic Press, Inc.; London: Academic Press, Inc. (London), Ltd., 1965.)

$\mathbf{N}$ the preface to Volume 4 of this book the editor says that fish as food is part of the epic of mankind. But, he points out in Volume 3 that: "Only through wise utilization and efficiont processing is it possible to save these extremely perishable riches of the oceans and fresh waters and place them within reach of the consuming public independent of seasons and of fishing fortunes...".
After death, fish deteriorates extremely quickly: even when packed with ice, biochemical changes commenco immediately as indicated by the progressive accumulation of dimethylamine in the flesh. For reasons not yet understood calamitous breakdown of fish catches may sometimes occur to produce, for example 'jellied' plaice or 'milky' hake. When environmental temperatures rise above $0^{\circ} \mathrm{C}$ spoilage can convert a "bin of sound fish to a soup or porridge. ..." in $24 \mathrm{~h}$.

The value of fish as food for man and its perishable nature have led from ancient times to the use of methods of preservation. Until comparatively recently, salting, drying and smoking were used. In addition to these techniques increasing use has been made since the last century of cooling and canning, and more recently of chemical additives.

No method of fish preservation is free from possible hazards. More than 4,000 years ago a Chinese wrote about the red discoloration of sea-water when it was allowed to stand and evaporate. This discoloration is due to the 'red-halophil' bacteria which can grow in high concentra. tion of salt and are the cause of the repulsive smell which sometimes develops in salted cod. Whereas most foods keep as well at temperatures up to $5^{\circ} \mathrm{C}$ as at $0^{\circ} \mathrm{C}$, this is not the case with fish, the bacterial contaminants of which begin to flourish as soon as temperatures rise above freez. ing-point. Preservation of fish by cooling therefore requires special means of refrigeration.

By and large, man has been successful in preserving fish so as to allow its wide utilization as food. Fish sauces, fish pastes, marinades, anchovies and other products have become established either as essential or luxurious items in the diets of different countries. The biological meckanisms of many traditional processing methods, and even the composition of some fish products, are not known. The techniques have evolved, not by the application of scientific knowledge, but from trial and error or by force of eireumstance. The high cost of salt about 200 years ago, for example, probably led the people of northern Sweden and Norway to use less of it than was needed to prevent growth of bacteria. As a result fermentation occurred and, by good chance, gave a product, fermented herring, which is harmless to eat and has become prized as a delicacy.

Tho practice of food technology is increasing rapidly, and as it does so much new knowledgo and many scientific and technical problems become apparent. This is particularly so in the case of fish processing; the discussions contained in the two volumes under review reveal the complexity of the problems and also that much is being done to try to resolve them. It is not enough to know that our forefathers preserved fish by smoking them in the household chimney. On the scale that smoking of fish is now required it is necessary to know about the chemical and physical nature of smoke itself, the costs of producing it, and how temperatures in smoke kilns can be controlled. The fish sauce of Vietnam is known in Franco as an exotic addition to the diet. But, in a world facing catastrophie shortage of food, the product may have much greator sigificance for, as revealed by modern analytical techniques, it contains appreciable amounts of essential amino-acids. Until about thirty years ago the watery byproduct obtained in the process of making fish meal was discarded. But the release of this waste not only caused serious pollution, but was a loss of valuable material. Fish solubles are now used as additions to animal feeds; they promote growth not only because of their vitamin content, but also because of the presence of a 'fish factor' the nature of which is unknown.

These aro but one or two examples of the many topics discussed by the different authors of the two volumes, which bring to completion the treatise, Fish as Food. Dr. Borgstrom is to be congratulated on editing, and substantially contributing to, a work which will surely remain for many years the standard exposition of the subject.
G. R. Wadsworth 